\title{
The Influence of European Cup Performances on Domestic Stadium Attendances in Romanian Football
}

\author{
Vlad I. ROȘCA \\ The Bucharest University of Economic Studies, Bucharest, Romania \\ vlad_rsc@yahoo.com
}

\begin{abstract}
Widespread belief posits that a relationship exists between results obtained in European football competitions and live attendances at domestic league games. As part of the Europeanization process, international tournaments increasingly attract fans' attention, often at the expense of national competitions, yet research up to date has focused on a wide array of explanatory variables for game attendance (spectator demand), but less on variables concerning how domestic teams perform in Europe. This article aims to fill the research gap by asking whether match attendances in national leagues can be predicted based on the results obtained by the domestic club teams in international competitions. UEFA team coefficients and domestic attendance figures for 74 European cup participations of Romanian teams spread over seventeen years from the 2000/2001 to the 2016/2017 season serve as input data for a regression model with an F-test and a p-value test. The Null Hypothesis instinctually claims no relationship exists between the variables, yet research results invalidate it for the good of the Alternative Hypothesis. The Discussions section presents what effects winning or losing in European cups can have on fans' motivation to come and watch matches in the national league.
\end{abstract}

Keywords: Europeanization, sports marketing, football marketing, pluralization.

\section{Introduction}

The consumption of professional team sports is a constituent in the formation of modern European culture (Tomlinson et al., 2011; Williams, 2007). Attending sports is one of the most popular leisure behaviors of Europeans, with thousands finding their ways to the stadium gates each weekend (Garcia, Zheng, 2012). Among all, football enjoys a priviledged position as the continent's most appealing sport, a reality that Romania has not fallen short of. A good deal of the Europeans' love with football has been influenced by UEFA's (The Union of European Football Associations) postbelic quest to enliven international club tournaments (Geeraert, 2016). The creation of the continent's two major competitions (the Champions League and the Europa League) has led to a pluralization of European football, spreading fans' attention between the matches played in the domestic leagues and the ones in the international cups.

As part of a widepsread Europeanization process, interest in continental competitions has gradually risen over the past sixty years, transforming football from a "national" to a "European" matter, with continental glory becoming the utmost indicator of sporting success (Mittag, Legrand, 2010). Mutz (2015) believes that, while also being concerned with what happens within their national boundaries, fans tend to shift attention towards more developped international contests, particularly so in the case of peripheral football states with less powerful national leagues. The attraction towards Eurpean cups can be explained through sporting, financial, or symbolic benefits associated with international participation (Leeds, von Allmen, 2016; Rülke, Stadtmann, 2008: 397). The Champions League and the Europa League are iconic brands enjoying increased popularity among fans, which leads to a reframing of European consciousness (King, 2000). Fans 
perceive European matchnights as an occasion to prove the qualities of their local team on a continental scale. Therefore, fans expect their teams to win not simply because this is the nature of sporting competition, but also because they want to receive international recognition. Recognition is then transferred from team to country level, leading to the manifestation of revived national consciousness and pride (Abell et al., 2007). With concentration directed towards obtaining good results in European tournaments, the question arises whether or not interest in attending upcoming domestic matches (against weaker opposition) has got to suffer as a consequence of how good or bad a team has recently performed in Europe.

The purpose of this research is to verify if results obtained in European cups have got any influence on the stadium attendances at matches played in the domestic football league. In aiming at this purpose, the article tries to extend the understanding of what drives spectator demand to attend matches. Albeit elevated research and many demand vectors having been investigated in recent history, the academic body has largely ommited to question as to if or how results produced in European competitions influence domestic attendances. The current paper tries to fill in this research gap by choosing Romanian football as its unit of observation. Much of the previous match attendance research has focused on reputable European leagues such as the English Premier League (Buraimo, 2008; Buraimo, Simmons, 2008), the French Ligue 1 (Scelles et al., 2013) or the Spanish La Liga (Buraimo et al., 2010), but interest in less stylish championships has been rather low (Andersson, Carlsson, 2011; Pawlowski, Nalbantis, 2015). This research casts a light upon both widely ignored attendance levers and geographical leagues by trying to answer the question of whether domestic attendances can be predicted based on European Cup performances? This may be relevant especially for people involved in football management and marketing. First of all, understanding what motivates supporters to attend matches live at the stadium allows football managers to make predictions and planifications for selling tickets and associated revenues. This provides a clearer image of the marketability of a football club and how much of the sporting activity can be transformed into entertainment to be commercialized. By knowing supporter motivations, sports managers can estimate not only the profitability of a football business, but also how good or poor a team might perform in front of crowds. It is known that crowd manifestations, but also crowd numbers have got a psychological impact on players (Azizi et al., 2017; Matsui et al., 1987; Schwartz, Barsky, 1977); subsequently, this leads to a certain influence on the final score of a football game, the most important variable in football management.

\section{Literature review}

Demand analysis is a cardinal motif in sports economy. Properly understanding the demand for sports is necessary for marketing professionals to make better decisions (Bradbury, O'Boyle, 2017), which has also headed the scientific literature towards offering particular attention to the mechanisms of demand generation. Several distinctive schools of thought can be identified herein, their evolution having been affected, over time, by the nature in which the landscape of professional sports has changed. A first, conventional route stresses the impact that usual economic variables such as price elasticity (Andersen, Nielsen, 2013; Chang et al., 2016; Krautmann, Berri, 2007), price discrimination (Watanabe, Soebbing, 
2017), income (Borland, MacDonald, 2003; Hynds, Smith, 1994) or expected quality (García, Rodríguez, 2002) have got on spectators demanding admission to stadiums. This is a bare approach that does not look at industry specifics, but only at customary microeconomic or macroeconomic variables with global applicability.

A more progressive avenue arised in parallel with the specialization of labor, which saw professional sports spring to the status of a particularized market having its own specifics. This approach brings into discussion several determinants likely to influence demand that are more specific to the sport activity in itself, such as in-league competition (Levin, 2009), team performance (Borland, Lye, 1992), competitve balance (García-Unanue et al., 2015; Nalbantis et al., 2017), loss aversion (Coates et al., 2014), outcome uncertainty (Coates, Humphreys, 2012), stadium location (Burke et al., 2008), stadium facilities (Roy, 2008), weather (Butler, 2002; Gibson et al., 2002; Jones et al., 2000), probability of a win (Falter, Pérignon, 2002), referee bias (Johnston, 2008), home side advantage (Nevill et al., 1996) or reputation of opponent (Czarnitzki, Stadtmann, 2002).

Last but not least, a third path going hand in hand with the previous one came in sight as societies as a whole have changed and matured, leading sports to adopt external influences for their benefit. Henceforth, studies started looking at the interactions between stadium attendance and broadcasting (Forrest et al., 2004) or star player reputation (Lawson et al., 2008).

Moving along the preceding rationale, studies should also consider the influence of internationalization on spectator demand, motivated by the globalization urge currently unfolding worldwide. Yet these studies have been largely ignored, although Europeanization, in particular, is a process that reframes cultural models around the continent, professional sports included (Fink-Hafner et al., 2015).

In the handful of studies concerned with the impact of Europeanization on domestic leagues, the focus is distributed between broadcasting and competitive balance, two of the liberal approaches that have grown once with the game becoming increasingly internationalized. Koenigstorfer et al. (2010) are asking in how far a domestic league and the Champions League can be attractive for fans in parallell. The authors come to demonstrate that, thanks to the millions in prize money, the top continental tournament creates a gap between participating and non-participating teams, which is then reflected in the national championship, with teams playing Champions League football enjoying a priviledged position (see also Andreff, 2012; Andreff, Szymanski, 2009; Menary, 2016). The key in keeping up the attractiveness of the domestic league for fans, then, resides in the ability of sports managers to maintain the competitive balance between rich and poor, for not having a league dominated only by the teams playing in Europe, which would translate through a reduced uncertainty of outcome. The relationship between European and domestic that the study has identified is that, primarily, competitive imbalance constrained by Champions League financial prizes might easily lead to a destabilization of the competitive balance in the national championship. Given that competitive balance is a guarantor of market efficiency and drives the fans' interest in sport (Fizel, 2017; Mourão, Cima, 2015), it can be assumed that an unbalanced domestic league will have to face declining attendances. A study explicitly concerning domestic gate attendance has been carried out by Forrest and Simmons (2006), who proved that televised live matches of 
domestic clubs playing in the Champions League lead to reduced attendances for lower tier clubs scheduled to play at the same time. The same is proved by Di Domizio (2013), who even discusses about a couch potato phenomenon, with football supporters prefering the more glamorous and comfortable option of staying at home and watching televised European quality football instead of going out to support their local team.

Bachan and Reilly (2016) provide one of the few researches to look at the relationship between European performances and domestic attendances. The authors use the UEFA country coefficient to predict attendance in the Irish Football League, identifying that a rise of the coefficient with one point yelds a $15.4 \%$ increase in match attendance (p. 270).

\section{Methodology}

Bachan and Reilly (2016) have opted for the average UEFA Country Coefficient as explanatory variable. The Country Coefficient is an indicator of a country's overall performance in Europe, computing an average on how all clubs teams have performed aggregately. Unlike this sort of approach, this paper takes into account all 74 individual European cup participations (the matches played in the UEFA Champions League and in the UEFA Europa League) that Romanian teams have enjoyed over the past seventeen years, starting with the 2000/2001 season and finishing with 2016/2017. Each year, the teams that are placed best in the final standings of the domestic championship are awarded participation rights to the aforementioned tournaments (Dunmore, 2011). The number of national teams entering European cups can vary from year to year depending on country performance index calculated by UEFA. The number of Romanian teams playing in Europe during a season has historically varied all the range between three and seven based on the evolution of the UEFA Country Coefficient. Over the analyzed period, Romanian football teams (either the same or different) have aligned at the start of European competitions in 74 instances.

An UEFA Team Coefficient (distinctive from the Country Coefficient) is calculated for each club playing in Europe. The Team Coefficient is computed as a sum of Qualification Points, Match Points and Bonus Points. These are UEFA points not to be confused with the usual points that are only awarded in round-robin stages where each team meets all other teams in turn and a final standing is calculated after all matches have been played, with three points awarded per win and one point per draw. European competitions also consist of knock-out stages, where no tournament points are being awarded any longer, but where a team has to qualify to the upcoming stage by having a better aggregate score than its opponent over two direct matches played, home and away. UEFA tracks the overall performance of the teams during the entire competitional season by awarding coefficient points (two per victory and one per draw) for either match played, irrespective of the stage (qualification, round-robin, or knock-out) and of the competition. In addition, bonus points are awarded for advancing to different milestones of the competitions. All in all, the UEFA Coefficient is a directly proportional indicator for a team's performance in Europe: the higher the success rate, the higher also the coefficient.

The UEFA Team Coefficient has been selected to be the explanatory x variable, while the dependent y variable was chosen to be the domestic average stadium attenances: the average number of spectators that a team has had at its home games during a season in the 
domestic championship. Average spectator numbers were computed by dividing the total number of fans that have come to the stadium to the number of matches played, so a seasonal average per match has been obtained. The spectator numbers taken into consideration were only the ones belonging to the teams participating both in the national league as well as in European cups for that particular season (hence, 74 inputs of spectator numbers). Raw data concerning average match attendances was collected from the European Football Statistics website, while the UEFA Coefficients were gathered from the Kassiesa portal.

The set of statistical analyses carried out included a Significance F-Test for overall significance of the model, a p-value for testing the Null Hypothesis and a Regression Analysis to test any potential variation in attendances. The Null Hypothesis (H0) states that there is no relationship between the results obtained in European competitions and stadium attendances in the domestic league (else told, it answers the research question in the negative, i.e. that domestic attendances cannot be predicted by the performances in European Cups).

\section{Results and discussions}

The results of the statistical analyses nullify the Null Hypothesis. The P-value (0.02) presented in Table 1 is lower than the alpha level of 0.05 , thus invalidating the Null Hypothesis and validating the Alternative Hypothesis.

Table 1. ANOVA and Regression Statistics

\begin{tabular}{|c|c|c|c|c|}
\hline & & Standard & & $P_{-}$ \\
\hline & Coef. & Error & tStat & value \\
\hline Intercept & 5624.04 & 601.832 & 9.344866 & 0.00 \\
\hline X Var. & 209.1132 & 89.88469 & 2.326461 & 0.02 \\
\hline
\end{tabular}

Source: Author's own research.

An ANOVA Significance F value of 0.022 (Table 2) indicates that the analysis carried out is statistically relevant, so that its results can be taken into consideration.

Table 2. ANOVA and Regression Statistics

\begin{tabular}{|c|c|c|c|c|c|c|c|}
\hline \multirow[b]{2}{*}{ ANOVA } & & & & & & $\begin{array}{c}\text { Regression } \\
\text { Statistics }\end{array}$ & \\
\hline & & & & & & Multiple R & 0.264418 \\
\hline & $d f$ & $S S$ & $M S$ & $F$ & Significance $F$ & R Square & 0.069917 \\
\hline Regression & 1 & 71016562.92 & 71016563 & 5.41 & 0.022812272 & Adjusted R Square & 0.056999 \\
\hline Residual & 72 & 944714918.71 & 13121041 & & & Standard Error & 3622.298 \\
\hline Total & 73 & 1015731482 & & & & Observations & 74 \\
\hline
\end{tabular}

The statistical results invalidate the idea by which there would be no influence of European Cup performances on domestic attendances. On the contrary, the P-value shows that the quality of results obtained by domestic Romanian clubs in European competitions 
has an impact on fans' decisions to go and attend matches live at the stadium in the domestic league. The Intercept value shows that, if the UEFA Coefficient was equal to zero (i.e. if Romanian football did not have any European performances at all), then the domestic average attendance per season would be situated at 5624 . Yet the actual average attendance for the observed period for this study was 6624, which lets understand that around 1000 spectators on average might just have been attracted to attend matches in the domestic league based on the European performances of Romanian football. Although a statistically significant relationship exists between the $\mathrm{x}$ and $\mathrm{y}$ values, the $\mathrm{R}$ Square value (0.069917) indicates that there is a rather low intensity of the impact of European cup results on spectator numbers, mainly that only $7 \%$ of variation in match attendances can be explained by UEFA Coefficients. The Coefficient values in Table 1 also show that each unit increase in UEFA coefficient points yields an attendance increase with 209 units (for each extra UEFA point won, 209 new fans will go and attend matches in the domestic league). At a first sight, this isn't a pregnant impact. However, several factors have to be taken into consideration. First of all, regarded from a football marketing perspective, given how UEFA coefficient points are awarded ( 0 points for a loss, 1 point for a draw, 2 points for a win) and taking into account that the coefficient represents the impact of one coefficient point on the modification of domestic match attendances, it can be said that the difference between losing and drawing a match in Europe consists of potential 209 fans on average that would go to attend a game in the national league if their team had at least drawn in Europe instead of losing. The same is true for the difference between drawing and winning a match in Europe, the latter being able to spark excitement among other 209 fans to attend games in the national league. Sumed up, winning a European match instead of losing it can motivate 418 fans to come to domestic games as well. Hence, even if they see their favorite team play live top-flight football against the crème-de-la-crème on the continent, the fans will still be interested in attending games against the weaker opposition in the domestic league, the difference in attendance numbers being made by the results in Europe. Second, these are only average attendance numbers. The average is calculated for all matches during a season, hence also those after the team has been presumably eliminated from European competitions, which would lead to a decrease in attendances. For coming to the average, this decrease would have to be compensated by higher gate numbers during the period in which the team still plays European matches, so the real impact on attendances while the team is still competing in Europe can be even greater. Also, over the past years, match attendances in the Romanian league have significantly dropped. In the 2016/2017 season, Pandurii Targu Jiu had an average of 625 fans per match. A victory in Europe would have meant a nearly doubled attendance figure, up to 1043, which indicates just how good a brand ambassador top performances in Europe can be for the football club. Last but not least, a long term perspective has to be considered. The better and the longer a team's participation in Europe, the higher also the UEFA coefficient. A team which is prematurely eliminated from Europe, i.e. in the preliminary rounds, will only have a low coefficient, without being able to considerably impact on domestic attendances. As competitional seasons both in Europe and in the national league run in parallel from July to May, it is important for teams to go past qualification stages and reach proper round football, if not even the knock-out stages of European cups: the longer the presence in Europe, the higher 
the impact will be. If a team is eliminated from European cups by August, even if it had won continental matches back then, the enthusiasm effects will diminish and even probably disappear by December. Continuing in Europe for as long as possible throughout the year builds momentum. This momentum stimulates fans to come closer to the team. For example, in the 2016/2017 season, Pandurii Targu Jiu was eliminated in August, in the qualifying rounds, having lost both its matches. No coefficient points were accumulated, so it can hardly be discussed about an impact had by European participation on the club's domestic attendances. On the contrary, Astra Giurgiu has qualified for the round of 32, staying in European competitions from August towards end of February, during which it has won three matches and drawn four against fashionable opposition. Momentum was built around these performances and fans were attracted. Considering the statistics, Astra Giurgiu had an average domestic attendance of 1975 during the season and an UEFA coefficient of 9.0. With the regression analysis showing an average increase of 209 fans per European point increase, it might be argued that, during the later stages of the competition, the impact of Astra's presence in European cups could have even lead to an average increase of 1881 fans per domestic home game, a figure nearly doubled to the real attendances. Thereupon, European participation is important for increased domestic attendances, but the length of the participation has also to be taken into account.

\section{Conclusion}

Research results present evidence that the quality of match results obtained in European competitions has got an impact on domestic league attendances. European results are a powerful brand ambassador acting upon the fans' perceptions towards their favourite teams. Internationalization (Europeanization, or Globalization alike) should be considered as a demand generating factor that needs to receive its share of interest in sports-oriented academic literature, at the crossroads of the progressive study avenues in attendance demand research. An influential reality of the 21st century, internationalization not only maintains or convulses competitive balances, but it also beholds strong marketing capabilities towards fans. This have helped Romanian football to enjoy a frail increase in gate figures. That the impact was not even higher was because European Cup performances of Romanian football clubs were not the best possible. However, the existence of a relationship between the variables should have decision-makers in Romanian football think about the possibilities of using European Cups as a solution to increase the quality of the domestic league, i.e. at the condition that serious investments are carried out in order to consolidate and to modernize Romania's position in European football.

\section{References}

Abell, J., Condor, S., Lowe, R.D., Gibson, S., \& Stevenson, C. (2007). Who ate all the pride? Patriotic sentiment and English national football support. Nations and Nationalism, 13(1), 97-116.

Andersen, P., \& Nielsen, M. (2013). Inelastic sports pricing and risk. Economics Letters, 118(2), 262-264.

Andersson, T., \& Carlsson, B. (2011). A diagnosis of the commercial immaturity of Swedish club football. Soccer \& Society, 12(6), 754-773. 
Andreff, W. (2012). Sport events, economic impact and regulation. In Michel Desbordes, and André Richelieu (Eds.). Global Sport Marketing: Contemporary Issues and Practice. Routledge, London/New York, pp. 83-109.

Andreff, W., \& Szymanski, S. (2009). Handbook on the Economics of Sport. Edward Elgar Publishing, Cheltenham/Northampton, MA.

Azizi, R., Esmaelzadeh, M. R., \& Sargolzae, N. (2017). Relationship between psychological well-being with creativity and performance of male coaches of Iran' basketball league. International Journal of Sport Studies, 7(2), 140-144.

Bachan, R., \& Reilly, B. (2017). Is the League of Ireland Under-supported? Evidence from a European perspective. Athens Journal of Sports, 3(4), 267-274.

Borland, J., \& Lye, J. (1992). Attendance at Australian Rules football: a panel study. Applied Economics, 24(9), 1053-1058.

Borland, J., \& MacDonald, R. (2003). Demand for sport. Oxford Review of Economic Policy, 19(4), 478-502.

Bradbury, T., \& O'Boyle, I. (eds.) (2017). Understanding Sport Management: International perspectives. Routledge, Oxon/New York.

Buraimo, B. (2008). Stadium attendance and television audience demand in English league football. Managerial and Decision Economics, 29(6), 513-523.

Buraimo, B., \& Simmons, R. (2008). Do sports fans really value uncertainty of outcome? Evidence from the English Premier League. International Journal of Sport Finance, 3(3), pp. 146-155.

Buraimo, B., Paramio, J.L., \& Campos, C. (2010). The impact of televised football on stadium attendances in English and Spanish league football. Soccer \& Society, 11(4), 461-474.

Burke, M., Evans, R., \& Hatfield, E. (2008). A Sporting Chance: Accessibility of proposed AFL stadium locations on the Gold Coast. Urban Research Program, Research Paper 18, September 2008, Griffith University, Brisbane, ISBN 978-1-921291-41-8.

Butler, M. R. (2002). Interleague play and baseball attendance. Journal of Sports Economics, 3(4), 320-334.

Chang, Y. M., Potter, J. M., \& Sanders, S. (2016). Inelastic sports ticket pricing, marginal win revenue, and firm pricing strategy: A behavioral pricing model. Managerial Finance, 42(9), 922-927.

Coates, D., \& Humphreys, B.R. (2012). Game attendance and outcome uncertainty in the National Hockey League. Journal of Sports Economics, 13(4), 364-377.

Coates, D., Humphreys, B.R., \& Zhou, L. (2014). Reference-dependent preferences, loss aversion, and live game attendance. Economic Inquiry, 52(3), 959-973.

Czarnitzki, D., \& Stadtmann, G. (2002). Uncertainty of outcome versus reputation: Empirical evidence for the First German Football Division. Empirical Economics, 27(1), 101112.

Di Domizio, M. (2013). Football on TV: An Empirical Analysis on the Italian Couch Potato Attitudes. Papeles de Europa, 26(1), 26-45.

Dunmore, T. (2011). Historical Dictionary of Soccer. The Scarecrow Press, Inc., Lanham/Toronto/Plymouth. 
Falter, J. M., \& Pérignon, C. (2000). Demand for football and intramatch winning probability: an essay on the glorious uncertainty of sports. Applied Economics, 32(13), 17571765.

Fink-Hafner, D., Hafner-Fink, M., \& Novak, M. (2015). Europeanisation as a factor of national interest group political-cultural change: The case of interest groups in Slovenia. East European Politics and Societies, 29(1), 287-305.

PICBE | 883

Fizel, J. (2017). Handbook of Sports Economics Research. Routledge, Oxon/New York.

Forrest, D., \& Simmons, R. (2006). New Issues in Attendance Demand. The Case of the English Football League. Journal of Sports Economics, 7(3), 247-266.

Forrest, D., Simmons, R., \& Szymanski, S. (2004). Broadcasting, attendance and the inefficiency of cartels. Review of Industrial Organization, 24(3), 243-265.

Garcia, B., \& Zheng, J. (2012). Football and Supporter Activism in Europe: Whose Game Is It?. Palgrave Macmillan/Springer International Publishing AG, Cham.

García, J., \& Rodríguez, P. (2002). The determinants of football match attendance revisited: Empirical evidence from the Spanish football league. Journal of Sports Economics, 3(1), 18-38.

García-Unanue, J., Godoy, A., Villarrubia, L., Sánchez-Sánchez, J., \& Gallardo, L. (2015). Balance competitivo en las ligas europeas de baloncesto y la NBA. Cultura, Ciencia y Deporte, 9(27), 235-242.

Geeraert, A. (2016). The EU in International Sports Governance: A Principal-Agent Perspective on EU Control of FIFA and UEFA. Palgrave Macmillan, Basingstoke.

Gibson, H., Willming, C., \& Holdnak, A. (2002). "We're gators... not just gator fans": Serious leisure and university of florida football. Journal of Leisure Research, 34(4), 397-425.

Hynds, M., \& Smith, I. (1994). The demand for test match cricket. Applied Economics Letters, 1(7), 103-106.

Johnston, R. (2008). On referee bias, crowd size, and home advantage in the English soccer Premiership. Journal of Sports Sciences, 26(6), 563-568.

Jones, J. C. H., Schofield, J. A., \& Giles, D. E. (2000). Our fans in the north: the demand for British Rugby League. Applied Economics, 32(14), 1877-1887.

King, A. (2000). Football fandom and post-national identity in the New Europe.The British Journal of Sociology, 51(3), 419-442.

Koenigstorfer, J., Groeppel-Klein, A., \& Kunkel, T. (2010). The attractiveness of national and international football leagues: Perspectives of fans of "star clubs" and "underdogs".

European Sport Management Quarterly, 10(2), 127-163.

Krautmann, A. C., \& Berri, D. J. (2007). Can we find it at the concessions? Understanding price elasticity in professional sports. Journal of Sports Economics, 8(2), 183-191.

Lawson, R.A., Sheehan, K., \& Stephenson, E.F. (2008). Vend it like Beckham: David Beckham's effect on MLS ticket sales. International Journal of Sport Finance, 3(4), 189-195.

Leeds, M., \& von Allmen, P. (2008). The Economics of Sports, Fifth Edition. Routledge, London/New York.

Levin, M. A. (2009). The value of competition: competitive balance as a predictor of attendance in spectator sports. International Journal of Sports Marketing and Sponsorship, 11(1), 2-19. 
Matsui, T., Kakuyama, T., \& Onglatco, M. U. (1987). Effects of goals and feedback on performance in groups. Journal of Applied Psychology, 72(3), 407-415.

Menary, S. (2016). One rule for one: the impact of Champions League prize money and Financial Fair Play at the bottom of the European club game. Soccer \& Society, 17(5), 666-679.

Mittag, J., \& Legrand, B. (2010). Towards a Europeanization of football? Historical phases in the evolution of the UEFA European Football Championship. Soccer \& Society, 11(6), 709-722.

Mourão, P. R., \& Cima, C. (2015). Studying the Golden Generations' Effects and the Changes in the Competitive Balance of the Portuguese Soccer League. International Journal of Sport Finance, 10(1), 42-61.

Mutz, M. (2015). Transnational Public Attention in European Club Football: Current trends and driving forces. European Societies, 17(5), 724-746.

Nalbantis, G., Pawlowski, T., \& Coates, D. (2017). The fans' perception of competitive balance and its impact on willingness-to-pay for a single game. Journal of Sports Economics, 18(5), 479-505.

Nevill, A.M., Newell, S.M., \& Gale, S. (1996). Factors associated with home advantage in English and Scottish soccer matches. Journal of Sports Sciences, 14(2), 181-186.

Pawlowski, T., \& Nalbantis, G. (2015). Competition format, championship uncertainty and stadium attendance in European football - a small league perspective. Applied Economics, 47(38), 4128-4139.

Roy, D. P. (2008). Impact of new minor league baseball stadiums on game attendance. Sport Marketing Quarterly, 17(3), 146-153.

Rülke, J.C., \& Stadtmann, G. (2008). The only way is up? Match Outcome and Stock Price Reactions of Borussia Dortmund GmbH \& Co. KgaA. In Patric Andersson, Peter Ayton, \& Carsten Schmidt (Eds.). Myths and Facts about Football: The Economics and Psychology of the World's Greatest Sport (pp. 393-418). Cambridge Scholars Publishing, Newcastle Upon Tyne.

Scelles, N., Durand, C., Bonnal, L., Goyeau, D., \& Andreff, W. (2013). My team is in contention? Nice, I go to the stadium! Competitive intensity in the French football Ligue 1. Economics Bulletin, 33 (3), 2365-2378.

Schwartz, B., \& Barsky, S. F. (1977). The home advantage. Social Forces, 55(3), 641-661. Tomlinson, A., Young, C., \& Holt, R. (eds.) (2011). Sport and the Transformation of Modern Europe: States, Media and Markets 1950-2010". Routledge, Oxon/New York.

Watanabe, N., \& Soebbing, B. (2017). Chinese Super League: attendance, pricing, and team performance. Sport, Business and Management: An International Journal, 7(2), 157174.

Williams, J. (2007). Rethinking Sports Fandom: The Case of European Soccer. Leisure Studies, 26(2), 127-146.

***European Football Statistics website, URL: http://www.european-footballstatistics.co.uk/attn.htm, retrieved on the 25th of September 2017.

***Kassiesa portal, URL: https://kassiesa.home.xs4all.nl/bert/uefa/index.html, retrieved on the 20th of September 2017. 